\title{
Genetic transformation of the Brazilian BR 451 maize variety by the Agrobacterium tumefaciens method
}

\author{
Marilia Rodrigues de Silva ${ }^{1}$ Dielli Aparecida Didoné ${ }^{1}$ \\ Cássia Canzi Ceccon ${ }^{1}$ Vinícius de Oliveira Almeida ${ }^{1}$ Magali Ferrari Grando ${ }^{1^{*}}$
}

'Laboratório de Biotecnologia Vegetal, Faculdade de Agronomia e Medicina Veterinária, Universidade de Passo Fundo (UPF), 99052-900, Passo Fundo, RS, Brasil. E-mail: magali@upf.br. "Corresponding author.

\begin{abstract}
The asexually gene introduction by genetic engineering has brought enormous possibilities to innovate plant breeding. However, principally because of the low in vitro response, genetic transformation has been restricted to only certain genotypes of agronomically significant species. With the objective of establishing a protocol for genetically transforming the Brazilian BR 451 maize variety through Agrobacterium tumefaciens, it was studied the capacity of plant regeneration in vitro from embryogenic calli cultivated in three regeneration media, each having different growth regulators. It was also evaluated the temperature stress effect on the transformation of the immature embryos with A. tumefaciens EHA 101 containing the plasmid pTF102 with uidA and bar genes. The BR 451 variety embryos and those of the Hi-II hybrid (control) were exposed to three treatments applied as they were being infected with the agrobacteria (a) infection at $25^{\circ} \mathrm{C}$; (b) infection at $40^{\circ} \mathrm{C}$; (c) pretreatment at $40^{\circ} \mathrm{C}$ for 5 seconds followed by infection at $25^{\circ} \mathrm{C}$. Transformation was determined by uidA gene expression and through the callus resistant to the herbicide Bialaphos ${ }^{\circledR}$ formation. Embryos infected at $40^{\circ} \mathrm{C}$ showed a higher degree of genetic transformation in the Hi-II, although the same was not noted in BR 451. When growth regulators were added to the culture medium the number of regenerated BR 451 plants showed no increase.
\end{abstract}

Key words: in vitro regeneration, temperature stress, EHA 101, pTF102, Zea mays.

Transformação genética da variedade brasileira de milho BR 451 pelo método da Agrobacterium tumefaciens

RESUMO: A introdução de genes de forma assexual por meio da engenharia genética tem ampliado as possibilidades do melhoramento genético vegetal. No entanto, devido principalmente a baixa resposta in vitro, a transformação genética tem se limitado a poucos genótipos das espécies de interesse agronômico. Visando estabelecer protocolo de transformação genética da variedade de milho BR 451 via Agrobacterium tumefaciens, foi estudada a capacidade de regeneração de plantas in vitro a partir de calos embriogênicos cultivados em três meios de regeneração contendo diferentes reguladores de crescimento. Também foi avaliado o efeito do estresse de temperatura na transformação de embriões imaturos com a A. tumefaciens EHA 101portadora do plasmideo pTF102 que contém os genes uidA e bar. Para tal, três tratamentos foram aplicados aos embriões da variedade BR 451 e do híbrido $\mathrm{Hi}$-II (controle) durante a infecção com a agrobactéria: (a) infecção em $25^{\circ} \mathrm{C}$; (b) infecção a $40^{\circ} \mathrm{C}$; (c) prétratamento de $40^{\circ} \mathrm{C}$ por cinco segundos seguido por infecção em $25^{\circ} \mathrm{C}$. A transformação foi avaliada mediante a expressão do gene uidA e a formação de calos resistentes ao herbicida Bialaphos ${ }^{\circledR}$. A infecção de embriões a $40^{\circ} \mathrm{C}$ aumentou a transformação genética em Hi-II, mas não em BR 451. A adição de reguladores de crescimento no meio de regeneração não incrementou o número de plantas regeneradas.

Palavras-chave: regeneração in vitro, estresse de temperatura, EHA 101, pTF102, Zea mays.

\section{INTRODUCTION}

Genetic engineering has made new sources of genetic variability available for plant breeding. Great efforts have been made to adapt gene transfer into cereals via $A$. tumefaciens as they are resistant to such maneuvers (FRAME et al., 2002; 2011). This recalcitrance is related to two different aspects: a) the low in vitro response (CARVALHO et al., 1997;
FRAME et al., 2006; GONZÁLES et al., 2012; GRANDO et al., 2013) e b) low explant sensibility to agrobacteria infection (VENNA et al., 2003; CARVALHO et al., 2004; WANG et al., 2007), thus restricting the number of transformed maize genotypes (GONZÁLEZ et al., 2012; OMBORI et al., 2014).

The Hi-II maize hybrid and its parents (A188 / B73) have been the most frequently used for genetic transformation (ISHIDA et al., 1996; FRAME 
et al., 2011); however, these genotypes possess inferior agronomic characteristics (ISHIDA et al., 2007). Therefore, it becomes necessary to adapt the A. tumefaciens-mediated transformation parameters to agronomically suitable genotypes, like varieties, hybrids and lines (FRAME et al., 2006; WANG et al., 2007; CARNEIRO et al., 2009; GONZÁLEZ et al., 2012).

The maize tropical variety BR-451, developed by Embrapa Milho and Sorgo (GUIMARÃES et al., 1997), possesses the ability to respond in vitro (CARVALHO et al., 1997). Besides, it exhibits precocity, lodging resistance, high protein content and ability to adapt to many areas in Brazil, which gives it an advantage over the Hi-II hybrid.

Employing genotypes that possess significant agronomic features (like the BR451 maize) and the increased degree of plant regeneration, as well as maintaining infection conditions that encourage the transfer of T-DNA from the agrobacteria to the plant genome (to thus produce a genetic transformation system adapted to alternative genotypes), facilitating the highest degree of genetic engineering and enhancing the quality of this culture in Brazil.

This study aimed to assess the possibility of genetically transforming the Brazilian maize BR 451 through $A$. tumefaciens, assessing if the high temperatures prevalent when the immature embryos are in the infection phase when $\mathrm{h}$ the bacterium raises the transient expression of the UidA reporter gene. This study aimed to confirm whether the growth regulators, when added, enhance in vitro plant regeneration of BR 451 maize variety.

\section{MATERIALS AND METHODS}

All the experiments were performed at the Laboratory of Plant Biotechnology at the Universidade de Passo Fundo, using the BR 451 variety of maize genotypes as well as the Hi-II hybrid (functioning as the control).

\section{Regeneration of the BR 451 maize plants}

BR 451 mature variety (1-2mm) embryos were cultured in the callus-induction medium according to GRANDO et al., (2013) until the embryogenic calli were formed. Ten subcultures later, the calluses were used for plant regeneration, which involved three stages: (a) germination of the somatic embryos and shoot formation; (b) shoot development and (c) rooting and seedling. One gram of embryogenic callus was distributed in a Petri dish $(100 \mathrm{~mm} \times 15 \mathrm{~mm})$ having $25 \mathrm{ml}$ of the different regeneration media to enhance bud formation: M1 - basic medium MS plus Erickson vitamins, $100 \mathrm{mg} \mathrm{L}^{-1}$ of myo-inositol, $60 \mathrm{~g} \mathrm{~L}^{-1}$ sucrose, $2 \mathrm{~g} \mathrm{~L}^{-1}$ phytagel, $\mathrm{pH} 5.8$; M2 - idem to M1 plus $0.5 \mathrm{mg}$ $\mathrm{L}^{-1}$ of BAP (HUANG \& WEI, 2004) and M3 - idem to $\mathrm{M} 1$, plus $1.5 \mathrm{mg} \mathrm{L}^{-1}$ of BAP and $0.5 \mathrm{mg} \mathrm{L}^{-1}$ of IBA (HUANG \& WEI, 2005).

All cultures were maintained for one week under dark conditions and then placed under fluorescence lamps of $36.75 \mu \mathrm{mol} \mathrm{m} \mathrm{m}^{-2} \mathrm{~s}^{-1}$ light intensity to ensure a 16 -hour photoperiod in $25 \pm 2{ }^{\circ} \mathrm{C}$. Subculturing was done of the calluses to fresh medium until the shoots emerged, which were then transferred to the MS medium with decreased sucrose concentration $\left(30 \mathrm{~g} \mathrm{~L}^{-1}\right)$ in the absence of growth regulators for the shoots to develop. Ten days later, the shoots were transferred to $300 \mathrm{ml}$ vials each with $30 \mathrm{ml}$ of half the concentration of MS salts and $30 \mathrm{~g} \mathrm{~L}^{-1}$ of sucrose for root and seedling development. Next, the $12 \mathrm{~cm}$ seedlings were potted (500ml) using equal quantities of MecPlant H01 substrate and carbonized rice husk (1:1) and placed in a humid chamber for 10 days. Finally, they were transferred to a greenhouse under shade cover. Fifteen days later, the plants were planted in to $10 \mathrm{~L}$ pots until maturity.

The following variables were analyzed: number of shoots, rooted seedlings, plants transferred for acclimatization, acclimatized adult plants and fertile plants per gram of callus. The completely randomized experimental design with five replicates was used, each of which was composed of a Petri dish containing one gram of embryogenic calli. All data were submitted to the analysis of variance.

Temperature stress on embryos infection with $A$. tumefaciens.

The transformation procedure and culture media employed were based on the protocol of FRAME et al. (2002). The immature embryos (1.2 to $2.0 \mathrm{~mm}$ ) belonging to the BR451 and $\mathrm{Hi}-\mathrm{II}$ genotypes were placed in the suspension containing the A. tumefaciens strain EHA101: pTF102 for five minutes in the dark, in the infection medium. Embryos at this time were treated at three temperatures: (1) infection at room temperature $\left(25^{\circ} \mathrm{C}\right)$; (2) infection at $40^{\circ} \mathrm{C}$; (3) pretreatment at $40^{\circ} \mathrm{C}$ for five seconds with exposure to infection at room temperature.

For three days, the infected explants were co-cultured with $A$. tumefaciens under conditions of darkness at $20^{\circ} \mathrm{C}$. They were then transferred to the Petri dishes with resting medium for seven 
days at $28^{\circ} \mathrm{C}$ and maintained in the dark. Next, the explants were transferred to the selection medium I supplemented with $1.5 \mathrm{mg} \mathrm{L}^{-1}$ of Bialaphos ${ }^{\circledR}$ and then they were transferred to selection medium II (with $3 \mathrm{mg} \mathrm{L}^{-1}$ of Bialaphos ${ }^{\circledR}$ ), continuing to maintain conditions of darkness at $28^{\circ} \mathrm{C}$. Finally, they were subcultured in the same medium every three weeks for six selection cycles until the herbicide resistant callus was formed. A completely randomized experimental design was adopted with 15 replications, where the experimental unit was a Petri dish containing 30 embryos. Transient transformation was evaluated using the GUS histochemical test (JEFFERSON et al., 1987) when the uidA gene (GUS) was expressed three days post infection. The percentage of bluespotted embryos were noted as well as the number of blue spots per GUS positive embryo; five embryos per replicate were used in this evaluation. The frequency of the callus formation resistant to the Bialaphos ${ }^{\circledR}$ herbicide was attained only in the sixth selection cycle.Treatments were compared by the means \pm 1 standard deviation.

Verification of the transformation was done by amplifying the bar gene by PCR employing the BarF primers (5'AGAAACCACGTCATGCC3') and $\operatorname{BarR}$ (5'TGCACCATCGTCAACCAC3') to react with $25 \mathrm{ng}$ of DNA; $2.5 \mathrm{nM}$ of each nucleotide; $2.5 \mu \mathrm{MgCl}$; $3 \mu \mathrm{l}$ buffer $(5 \mathrm{X}) ; 0.15 \mu \mathrm{L}$ Taq polymerase $(5 \mathrm{U}$ per $\mu \mathrm{L})$; $10 \mu \mathrm{M}$ of primer $1 ; 10 \mu \mathrm{M}$ of primer 1 in $25 \mu \mathrm{L}$ of the final volume. The amplification was done by going through one cycle of $94^{\circ} \mathrm{C}(2 \mathrm{~min}), 35$ cycles of $94^{\circ} \mathrm{C}$ (20s), $54^{\circ} \mathrm{C}(20 \mathrm{~s}), 72^{\circ} \mathrm{C}(30 \mathrm{~s})$ and the final extension of $72^{\circ} \mathrm{C}$ (4min). Analysis of the amplified product occurred through agarose gel electrophoresis $0.8 \%$; staining was done using ethidium bromide and finally observed in translucent using an ultraviolet lamp (254nm).

\section{RESULTS AND DISCUSSION}

\section{Regeneration of BR451 maize plants}

Complete and fertile BR 451 plants could be regenerated (Figure 1A). When the BAP and IBA growth regulators were added to the culture medium, regeneration was not affected. An average of 6.4 shoots, 5.4 rooted seedlings and 3.8 plants were subjected to acclimatization and three adult acclimatized plants per gram of callus were produced. These plants were fertile, allowing the transferred characteristics to the offspring, what is important in case of genetic transformation.

Unlike the results observed in this research, HUANG \& WEI (2004) verified the effect of $0.5 \mathrm{mg} \mathrm{L}^{-1} \mathrm{BAP}$ on the frequency of shoots of twines. Adopting a similar method, HUANG \& WEI (2005) improved the regeneration of maize plants in vitro employing a combination of $1.5 \mathrm{mg} \mathrm{L}^{-1} \mathrm{BAP}$ and $0.5 \mathrm{mg} \mathrm{L}^{-1}$ IBA. The plant regeneration procedures normally need some alterations for different maize genotypes (CARNEIRO, 2009; FRAME et al., 2011). In comparison with the other maize genotypes the BR451 regeneration profile reported in this study was satisfactory (three adult plants/ gram of callus). In their experiments CARVALHO et al. (1997) produced between 3.1 and 7.7 plants per gram of callus in 42 tropical lines, including the BR 451 variety, in MS medium, in the absence of growth regulators; although, the authors did not specifically mentioned the frequency of plant regeneration for this variety. The MS medium without the addition of regulators was selected for future regeneration experiments of the BR 451 transgenic plants. This is the same medium used in vitro for the genetic transformation of the responsive maize genotypes (FRAME et al., 2002; 2006).

Effect of temperature on the infection of embryos with A. tumefaciens

When temperature stress was applied at the time of infecting the immature embryos with A. tumefaciens, the frequency of the blue-spotted embryos increased by $50 \%$, as well as the number of blue spots per embryo to $15 \%$, and the percentage of herbicide-resistant callus rose to $29.6 \%$ for $\mathrm{Hi}$-II alone (Table 1). The blue dots highlighted the sites where the uidA gene present in the agrobacteria T-DNA was inserted into the maize embryo. This is a measure of transient genetic transformation.

ISHIDA et al., (2007) recorded the positive effect of temperature shock when they achieved 52\% transformation using physical stress, plus a temperature of $46^{\circ} \mathrm{C}$ for $3 \mathrm{~min}$ prior to infecting maize embryos. In like manner, pre-treatment at $43^{\circ} \mathrm{C}(3 \mathrm{~min})$ prior to bacterial infection increased the sorghum transformation frequency from $2.6 \%$ to $7.6 \%$ (GUREL et al., 2009). However, the current experiment indicated that the temperature stress was efficient only when applied during the infection phase. High temperatures were reported to support transformation, most likely by increasing the cell wall permeability (VASCONCELOS et al., 2008). This type of stress could also decrease the degree of the plant tissue defense response to bacterial infection and/or stimulate the protein-controlling genes that assist in activating the vir region.

Apart from the Hi-II hybrid revealing a positive response when exposed to the infection at 


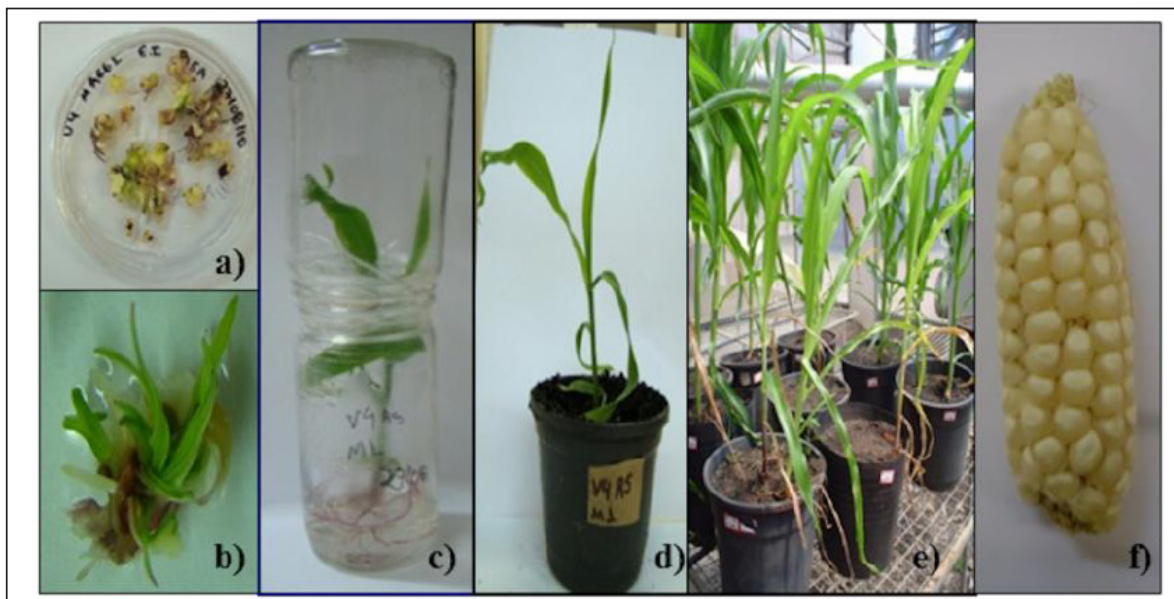

B) UidA gene expression in immature embryos

\begin{tabular}{|l|l|l|l|l|}
\hline Genotype & Infection at $25^{\circ} \mathrm{C}$ & Infection at $40^{\circ} \mathrm{C}$ & $\begin{array}{l}\text { Pretreatment at } 40^{\circ} \mathrm{C} \text { for } \\
5 \text { seconds followed by } \\
\text { infection at } 25^{\circ} \mathrm{C} .\end{array}$ & $\begin{array}{c}\text { callus resistant to } \\
\text { Bialaphos } 8 \\
\text { herbicide }\end{array}$ \\
\hline Hi-II & & & & \\
\hline BR 451 & & & & \\
\hline
\end{tabular}

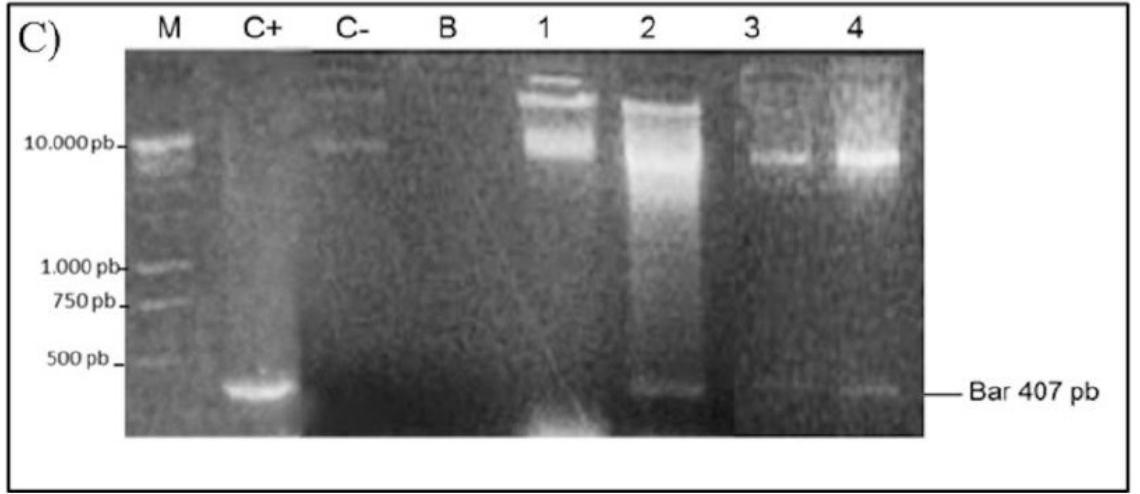

Figure 1 - Regeneration of plants in vitro and genetic transformation of the maize BR 451 variety. A) In vitro regeneration process. a, b) bud formation from embryogenic calli cultivated in M1 regeneration medium; c) maize seedlings in flasks containing $1 / 2 \mathrm{MS}$; d) plant acclimatized in pot with substrate; e) potted plants in greenhouses; f) Ear produced by plant regenerated in vitro in M1 medium. B) Expression of the uidA gene (blue spots) after GUS histochemical assay on immature embryos submitted to different temperature treatments in the infection stage with A. tumefaciens and callus resistant to the Bialaphos ${ }^{\circledR}$ herbicide of the Hi-II and BR 451 genotypes after six cycles of selection. C) PCR analysis for the bar gene in callus resistant to the herbicide Bialaphos ${ }^{\circledR}$. M: 1000pb marker; C+: isolated plasmid DNA from the A. tumefaciens EHA101: pTF102 as a positive control; C-: untransformed callus as negative control; B: Blank; 1: negative callus for bar gene; 2,3,4: embryogenic calli containing the bar gene presenting a PCR amplified 407bp fragment, Passo Fundo, FAMV/UPF, 2014. 
Table 1 - Expression of the uidA gene and the production of Bialaphos ${ }^{\circledR}$ herbicide resistant calli in two maize genotypes submitted to different treatments in the stage of infection of immature embryos with Agrobacterium tumefaciens EHA101/pTF102. Passo Fundo, FAMV/UPF, 2012.

\begin{tabular}{|c|c|c|c|c|}
\hline Genotype & Treatment & $\begin{array}{l}\text { Percentage of } \\
\text { embryos with blue } \\
\text { spots }\end{array}$ & $\begin{array}{l}\text { Number of blue } \\
\text { spots per embryo }\end{array}$ & $\begin{array}{l}\text { Percentage of } \\
\text { Bialaphos } \\
\text { resistant callus }\end{array}$ \\
\hline Hi-II & infection at $25^{\circ} \mathrm{C}$ & 31 & 7 & 18.2 \\
\hline Hi-II & infection at $40^{\circ} \mathrm{C}$ & $50 \mathrm{~S}$ & $15 \mathrm{~S}$ & $29.6 \mathrm{~S}$ \\
\hline Hi-II & pretreatment at $40^{\circ} \mathrm{C}$ followed by infection at $25^{\circ} \mathrm{C}$. & 22 & 5.4 & 19.1 \\
\hline Mean & & 34.3 & 9.3 & 22.3 \\
\hline BR 451 & infection at $25^{\circ} \mathrm{C}$ & 13.6 & 1.6 & 7.4 \\
\hline BR 451 & infection at $40^{\circ} \mathrm{C}$ & 11.7 & 1.1 & 1.1 \\
\hline BR 451 & pretreatment at $40^{\circ} \mathrm{C}$ followed by infection at $25^{\circ} \mathrm{C}$. & 12.6 & 8.5 & 8.5 \\
\hline \multirow[t]{3}{*}{ Mean } & & 12.7 & 3.7 & 5.6 \\
\hline & $M+1 d p$ & 43.4 & 10.7 & 24.5 \\
\hline & $M-1 d p$ & -9.7 & -3.7 & -4.6 \\
\hline
\end{tabular}

$\mathrm{S}=$ superior (Mean plus one standard deviation).

high temperature, it also showed blue-spotted double embryos (34.3\%) compared with the BR $451(12.7 \%)$ variety. Similarly, the number of blue spots per embryo in the Hi-II increased (9.3 points/embryo) and was more than the BR 451 (3.7) showing a higher frequency of Bialaphos $^{\circledR}$ resistant callus $(22.3 \%)$ compared with the BR 451 (5.6\%) (Table 1; Figure 1B). The better transformation ability of the Hi-II with agrobacteria has been extensively reported in the literature (ISHIDA et al., 1996; HUANG \& WEI, 2005; FRAME et al., 2011).

The difference evident in the response of the genotypes to the transformation is attributed possibly to the variability in the proteins produced, which play a role in the transfer of the agrobacteria T-DNA (ZHANG et al., 2000) and in the plant defense response (VEENA et al., 2003). HWANG \& GELVIN (2004) reported that agrobacterial infection induces the plant genes responsible for transformation to be expressed, and at the same time repressed in the host defense response genes.

The presence of the bar gene, which determines the resistance to the Bialaphos ${ }^{\circledR}$ herbicide, was identified in the resistant callus via the PCR method. In Figure 1C the amplification of the bar gene in certain calli of the Hi-II and BR451 genotypes is evident. However, the bar gene was missing in some resistant calli, implying the presence of scapes, which entails adjustment of the selection pressure to the selective process. This study is the first report of the genetic transformation of the BR 451 maize genotype via $A$. tumefaciens.

\section{CONCLUSION}

The maize BR 451 variety was amenable to genetic transformation utilizing A. tumefaciens, implying the likelihood of its use in generating genetically modified plants with significant agronomic genes. When the immature embryos of this variety were infected by the agrobacteria, the application of temperature stress does not affect the transient transformation of the reporter gene. Similarly, when growth regulators were added to the culture medium the regeneration of the BR 451 plants was not encouraged.

\section{ACKNOWLEDGEMENTS}

We are grateful to Dra. Andreia Almeira Carneiro from Embrapa Maize and Sorghum for the concession of the BR 451 maize variety.

\section{REFERENCES}

CARNEIRO, A.A. et al. Transformação genética de embriões zigóticos da linhagem de milho tropical L3 mediada por Agrobacterium tumefaciens. Sete Lagoas: Embrapa Milho e Sorgo, 2009. 16p. (Circular técnica, 132).

CARVALHO, C.H.S. et al. Type II callus production and plant regeneration in tropical maize genotypes. Plant Cell Reports, v.17, n.1, p.73-76, 1997. Available from: <http://ainfo.cnptia.embrapa.br/digital/ bitstream/item/43433/1/Type-callus.pdf $>$. Accessed: Ago. 10, 2012.

CARVALHO, C.H.S. et al. Agrobacterium-mediated transformation of sorgum: factors that affect transformation efficiency. Genetic and 
Molecular Biology, v.27, n.2, p.259-269, 2004. Available from: $<$ http://www.scielo.br/pdf/gmb/v27n2/a22v27n2.pdf $>$. Accessed: June 06, 2011. doi: 10.1590/S1415-47572004000200022.

FRAME, B.R. et al. Agrobacterium tumefaciens-mediated transformation of maize embryos using a standard binary vector system bbreakthrough technologies. Plant Physiology, v.129, n.1, p.13-22, 2002. Available from: $<$ http://www.plantphysiology. org/content/129/1/13. full. pdf $>$. Accessed: Feb. 06, 2010. doi: $10.1104 /$ pp.000653.

FRAME, B.R. et al. Improved Agrobacterium-mediated transformation of three maize inbred lines using MS salts. Plant Cell Reports, Genetic Transformation and Hybridization, v.25, n.10, p.1024-1034, 2006. Available from: <http://agron-www. agron.iastate.edu/ptf/ publications/bf-pcr_2006.pdf>. Accessed: Feb. 06, 2010. doi: 10.1007/s00299-006-0145-2.

FRAME, B. et al. Genetic transformation using maize immature zygotic embryos. In: THORPE, A.; YEUNG, E.C. Plant embryo culture: methods and protocols: methods in molecular biology. New York: Springer, 2011. Cap. 22, p.327-341.

GONZÁLEZ, G.A. et al. Somatic embryogenesis and plant regeneration capacity in Argentinean maize (Zea mays L.) inbred lines. Electronic Journal of Biotechnology, v.15, n.1, p.1-15, 2012. Available from: <http://www.scielo.cl/pdf/ejb/v15n1/a09.pdf $>$. Accessed: Mar. 10, 2013. doi: 10.2225/vol15-issue1-fulltext-7.

GRANDO, M.F. et al. Immature tassels as alternative explants in somatic embryogenesis and plant regeneration in south Brazilian maize genotypes. Acta Scientiarum Agronomy, v.35, n.1, p.3-17, 2013. Available from: <http://periodicos.uem.br/ojs/index. php/ ActaSciAgron/article/view/15545/pdf>. Accessed: July 05, 2013. doi: 10.4025/actasciagron.v35i1.15545.

GUIMARÃES, P.E.O. et al. Quality protein maize improvement at the National Maize and Sorghum Research Center - CNPMS/EMBRAPA/ BRAZIL. In:. LARKINSAND, B.A.; MERTZ, E.T. (Eds.). Quality protein maize:1964-1994. USA: Purdue University-, 1997. p.185-203.

GUREL, S. et al. Efficient, reproducible Agrobacterium-mediated transformation of sorghum using heat treatment of immature embryos. Plant Cell Reports, v.28, n.3, p.429-444, 2009. Available from: $<$ http:// download.springer.com/static/pdf/176/art\%253A10.1007\%252Fs 00299-008-0655-.pdf?auth66=139733511792a5f57bfbf98d20ed3b c329c746630a\&ext=.pdf $>$. Accessed: June 05, 2011. doi: 10.1007/ s00299-008-0655-1.

HUANG, X.Q.; WEI, Z.M. High-frequency plant regeneration through callus initiation from mature embryos of maize (Zea mays L.). Plant Cell Reports, v.22, n.11, p.793-800, 2004. Available from: <http:// download.springer.com/static/pdf/110/art\%253A10.1007\%252Fs00 299-003-0748-9.pdf?auth66=1397335298_162487c30a432aa468 5 a932 e2 ddf525\&ext=.pdf>. Accessed: May 02, 2009. doi: 10.1007/ s00299-003-0748-9.

HUANG, X.Q.; WEI, Z.M. Successful Agrobacterium-mediated genetic transformation of maize elite inbred lines. Plant Cell, Tissue and Organ Culture, v.83, n.2, p.187-200, 2005. Available from: $<$ http://download.
springer.com/static/pdf/799/art\%253A10.1007\%252Fs 11240-005-57728.pdf?auth66=1397409021d367e9ffb4452aee07ad01f3be2aa48\&ext=. pdf>. Accessed: May 02, 2009. doi: 10.1007/s11240-005-5772-8.

HWANG, H.H.; GELVIN, S.B. Plant proteins that interact with VirB2, the Agrobacterium tumefaciens pilin protein, mediate plant transformation. Plant Cell, v.16, p.3148-3167, 2004. Available from: <file://C:/ Users/upf/Documents/01\%20milho/Marilia/Artigo $\% 20$ para $\% 20$ publica $\%$ C3\%A7\%C3\%A3o/BR451/Hwang\%20e\%20Gelvin, $\% 20$ 2004.pdf>. Accessed: May 23, 2012. doi: 10.1105/tpc.104.026476.

ISHIDA, Y. et al. Agrobacterium mediated transformation of maize. Nature Protocols, v.2, n.7. p.1614-1621, 2007. Available from: $<\mathrm{http}$ ://www.nature.com/nprot/ journal/v2/n7/pdf/nprot.2007.241. pdf $>$. Accessed: Apr. 09, 2009. doi: 10.1038/nprot.2007.24.

ISHIDA, Y. et al. High efficiency transformation of maize (Zea mays L.) mediated by Agrobacterium tumefaciens. Nature Biotecnology, v.14, n.16, p.745-750, 1996. Available from: <http://www.nature. com/nbt/journal/v14/n6/pdf/nbt0696-745.pdf>. Accessed: June 07, 2014. doi: $10.1038 /$ nbt0696-745.

JEFFERSON, R.A. et al. GUS fusions: beta-glucuronidase as a sensitive gene fusion marker in high plants. Embo Journal, v.6, n.13, p.3901-3907, 1987. Available from: <http://www.ncbi.nlm. nih.gov/pmc/articles/PMC553867/pdf/emboj00253-0035.pdf >. Accessed: Jan. 18, 2007.

OMBORI, O. et al. Agrobacterium mediated genetic transformation of selected tropical inbred and hybrid maize (Zea mays L.) lines. Plant Cell Tissue Organ Culture, v.113, p.11-23, 2013. Available from: $<$ http://link.springer.com/article/10.1007\%2Fs11240-012-0247-1\#/ page-1>. Accessed: June 07, 2014. doi: 10.1007/s11240-012-0247-1.

VASCONCELOS, M.J.V. SAAT: sonicated assisted agrobacterium mediated transformation of tropical maize embryos. Revista Brasileira de Milho e Sorgo, v.7, n.2, p.105-112, 2008. Available from: <http://www.alice.cnptia.embrapa.br/alice/bitstream/doc/48696 8/1/MariaJose2.pdf $>$. Accessed: Mar. 18, 2012. doi: 10.18512/19806477/rbms.v7n2p105-112.

VEENA, J.H. et al. Transfer of T-DNA and Vir proteins to plant cells by Agrobacterium tumefaciens induces expression of host genes involved in mediating transformation \& suppresses host defense gene expression. Plant Journal, v.35, n.2, p.219-236, 2003. Available from: <http:// onlinelibrary.wiley.com/doi/10.1046/j.1365-313X.2003.01796.x/epdf>. Accessed: Feb. 10, 2013. doi: 10.1046/j.1365-313X.2003.01796.x.(?).

WANG, Y. et al. Selection of maize inbred lines with high regeneration and susceptibility to Agrobacterium tumefaciens. Journal of Genetics and Genomics, v.34, n.8, p.749-755, 2007. Available from: <http:// www.sciencedirect.com /science/article/pii/S1673852707600848>. Accessed: Ago. 20, 2009. doi: 10.1016/S1673-8527(07)60084-8.

ZHANG, J. et al. At the maize/Agrobacterium interface: natural factors limiting host transformation. Chemical Biology, v.7, n.8, p.611-621, 2000. Available from: <http://ac.els-cdn.com/S1074552100000077/1s2.0-S1074552100000077-main.pdf?tid=ef6a70fa-a03a-11e5-878400000aacb361\&acdnat $=14498612494 \mathrm{e} 0 \mathrm{c} 156 \mathrm{~b} 081 \mathrm{a} 45 \mathrm{dbf9} 14 \mathrm{ea6e} 761 \mathrm{f}$ cff3>. Accessed: Mar. 22, 2011. doi: 10.1016/S1074-5521(00)00007-7. 